ATTHULAB:

Islamic Religion Teaching \& Learning Journal

Volume 4 Nomor 2 Tahun 2019

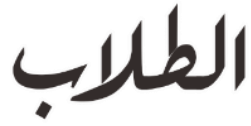

http://journal.uinsgd.ac.id./index.php/atthulab/

\title{
Profil pemahaman standar proses tenaga pendidik di sekolah
}

\author{
Mohammad Reza Arianto \\ Sekolah Menengah Atas Negeri 1 Jatitujuh Majalengka \\ Jalan Rentang Baru Jatitujuh Majalengka Jawa Barat 45458 Indonesia \\ Email: mrezaarianto21@gmail.com
}

\begin{abstract}
The achievement of national education standards for schools is one of the successes and quality of education, so this study aims to obtain a profile of understanding and achievement of national education standards within the school. The research method used was descriptive qualitative using interview guidelines on national education standards. Data sources were obtained from five people. The results showed there were variations in understanding of standard processes. In addition there are variations in the components / aspects of the standard process that are understood by the teachers. So the results of this study have implications for the importance of the socialization of standard evaluation components to all educators in a school.
\end{abstract}

Keywords:

assessment standards; national standard of education

\begin{abstract}
Pencapaian standar nasional pendidikan bagi sekolah merupakah salah satu keberhasilan dan mutu pendidikannya, sehingga penelitian ini bertujuan untuk memperoleh profil pemahaman dan pencapaian standar nasional pendidikan dilingkunagn sekolah. Metode penilitan yang digunakan adalah deskriptif kualitatif dengan menggunakan pedoman wawancara tentang standar nasional pedidikan. Sumber data diperoleh dari lima orang. Hasil penelitian menunjukan ada variasi pemahaman tentang standar proses. Selain itu terdapat variasi komponen/aspek standar proses yang dipahami oleh guru-guru. Sehingga hasil penelitian ini berimplikasi terhadap pentingnya sosialisasi komponen-komponen standar evaluasi kepada seluruh pendidik disuatu sekolah.
\end{abstract}

Kata kunci:

standar penilaian; standar nasional pendidikan

DOI: http://dx.doi.org/10.15575/ath.v4i2.4958

Received: 06, 2019. Accepted: 10, 2019. Published: 11, 2019

\section{PENDAHULUAN}

Pencapaian standar nasional pendidikan bagi sekolah merupakah salah satu keberhasilan dan mutu pendidikannya, sehingga penelitian ini bertujuan untuk memperoleh profil pemahaman dan pencapaian standar nasional pendidikan dilingkunagn sekolah.

Standar Proses untuk Satuan Pendidikan Dasar dan Menengah yang ditetapkan berdasarkan Permendiknas Nomor 41 Tahun 2007 merupakan salah satu acuan utama bagi satuan Pendidikan dalam keseluruhan proses penyelenggaraan pembelajaran, mulai dari perencanaan proses pembelajaran, pelaksanaan proses pembelajaran, penilaian hasil pembelajaran dan pengawasan proses pembelajaran. Pemberlakuan standar proses padasatuan pendidikan diharapkan dapat meningkatkan mutu lulusan dalam mencapai standar kompetensi lulusan yang pada akhirnya mampu meningkatkan mutu pendidikan. Oleh karena itu, proses pembelajaran di setiap SMA harus menerapkan prinsip pembudayaan dan pemberdayaan peserta didik 
sesuai dengan potensi, bakat dan minat masing-masing. Selain itu, proses pembelajaran harus dilaksanakan secara fleksibel dengan memanfaatkan seluruh sumber daya yang tersedia baik di dalam maupun di luar sekolah. Dari penjelasan tersebut di atas dapat disimpulkan bahwa standar proses memiliki peran yang sangat penting dalam keseluruhan proses pencapaian standar nasional pendidikan lainnya. (Manoppo, 2014)

Sebuah proses pendidikan, baik tingakatan nasional maupun tingkatan kelas akan dianggap sukses apabila kompetensi lulusan yang ditargetkan dapat tercapai dengan sempurna. Oleh sebab itu, diperlukan beberapa tahapan-tahapan dan serangkai strategi yang nantinya dijadikan pedoman untuk mencapai target tersebut

Secara konseptual, kurikulum merupakan suatu respon pendidikan terhadap kebutuhan masyarakat dan bangsa dalam membangun generasi muda bangsanya. Kurikulum harus menjamin pemberdayaan siswa pada semua aspek kompetensi, yang memungkinkan siswa siap menjadi warga masyarakat yang bermutu. Oleh pihak sekolah, pemberdayaan siswa dilakukan dengan segala cara, menata proses pembelajaran sesuai situasi dan lingkungannya. (Anon., Februari 2012)

Usaha yang dilakukan pemerintah pusat untuk mencapai tujuan pendidikan nasional, diantaranya melengkapi sarana sekolah, menyempurnakan strategi yang bisa digunakan untuk diimplementasikan di kelas, melakukan sertifikasi guru yang bertujuan untuk menunjang terlaksananya pendidikan dengan baik dan penyempurnaan kurikulum dari KBK tahun 2004 sampai KTSP tahun 2006. Selain itu, KTSP menuntut peserta didik berfikir ilmiah, menemukan konsep sendiri serta melaksanakan penilaian berbasis kelas. (Chodijah \& Ahmad Fauzi, 2012)

Guru berperan penting dalam upaya peningkatan kualitas pendidikan yang berkaitan dengan tugas pokok dan fungsinya sebagai pendidik. Untuk menyelenggarakan pembelajaran aktif, kreatif, efektif dan menyenangkan, maka guru perlu merancang perencanaan pembelajaran, pemilihan model pembelajaran yang bervariasi, media yang menarik, dan alat evaluasi yang baik.

Seorang guru melaksanakan proses pembelajaran di kelas terlebih dahulu mempersiapkan model pembelajaran yang sesuai dengan perangkat pembelajaran yang tersedia. Melalui perangkat pembelajaran yang digunakan tergambar muatan yang akan diberikan kepada peserta didik, sehingga terjadi perubahan kompetensi peserta didik terhadap materi pembelajaran. (U.S., n.d.)

Selain itu, dalam PP nomor 19 tahun 2005 Pasal 20 dinyatakan bahwa guru diharapkan mengembangkan materi pembelajaran dan mensyaratkan bagi pendidik pada satuan pendidikan untuk mengembangkan RPP. Salah satu elemen dalam RPP adalah sumber belajar, sehingga guru diharapkan untuk mengembangkan bahan ajar sebagai salah satu sumber belajar. (Rahmawati, Desi Anggraini, 2017)

\section{METODE PENELITIAN}

Metode penilitan yang digunakan dalam pembahasan artikel ini adalah deskriptif kualitatif dan metode pendekatan desriptif analisis. Deskritif analisis yaitu metode yang digunakan untuk memecahkan permasalahan dengan cara memaparkan atau menggambarkan hasil dari suatu penelitian. Sumber data diambail dari hasil penelitian pengumpulan data dengan mengamati dan dan mencatat terhadap fenomena yang diselidiki dengan cara wawancara tentang standar proses pendidikan, kemudian mengambil kesimpulan dengan menganalisis. Hal ini sesusai dengan penelitian kualitatif sebagai penelitian yang bermaksud untuk memahami fenomena tentang apa yang dialami oleh subjek penelitian atau dari orang-orang, misalnya perilaku, persepsi, 
motivasi, tindakan, dan lain-lain, secara holistik dan dengan cara deskripsi dalam bentuk kata-kata dan bahasa, pada suatu konteks khusus yang alamiah dan dengan memanfaatkan berbagai metode alamiah. (Moleong, 2013). Sumber data dalam penelitian ini dari sumber data dengan menggunakan pedoman wawancara berkiatan tentang standar nasional pedididkan. Sumber data diperoleh dari 5 (lima) orang guru. Sumber data penunjang berasal dari dokumen, profil sekolah SMAN 1 Jatitujuh.

\section{HASIL PENELITIAN DAN PEMBAHASAN}

Berdasarkan analisis data pemahaman dan kemampuan tenaga pendidik terhadap standar proses diperoleh profil pemahaman tenaga pendidik dan profil analisis komponen-komponen standar proses pada sekolah SMAN 1 Jatutujuh. Untutk mengetahui pemahaman pendidik terhadap standar proses, maka peneliti mewancarai guru-guru dengan 43 pernyataan komponen standar pendidikan pada standar proses.

\section{Profil pemahaman tenaga pendidik} berikut:

Profil pemahaman tenaga pendidik dapat ditunjukkan dengan table dan grafik

Tabel.1 komponen standar proses

\begin{tabular}{|c|c|c|c|c|c|c|}
\hline \multirow{2}{*}{ No } & \multirow{2}{*}{ Pernyataan } & \multicolumn{5}{|c|}{ Keterangan } \\
\hline & & Guru-1 & Guru-2 & Guru-3 & Guru-4 & Guru-5 \\
\hline 1 & Perencanaan Pembelajaran, Silabus & $\sqrt{ }$ & $\sqrt{ }$ & $\sqrt{ }$ & $\sqrt{ }$ & $\sqrt{ }$ \\
\hline 2 & $\mathrm{RPP}$ & $\sqrt{ }$ & $\sqrt{ }$ & - & - & $\sqrt{ }$ \\
\hline 3 & Kalender Pendidikan & $\sqrt{ }$ & $\sqrt{ }$ & $\sqrt{ }$ & $\sqrt{ }$ & $\sqrt{ }$ \\
\hline 4 & Progrma Tahunan & $\sqrt{ }$ & $\sqrt{ }$ & $\sqrt{ }$ & $\sqrt{ }$ & $\sqrt{ }$ \\
\hline 5 & Program Semester & $\sqrt{ }$ & $\sqrt{ }$ & $\sqrt{ }$ & $\sqrt{ }$ & $\sqrt{ }$ \\
\hline 6 & Alokasi Waktu Program Semester & $\sqrt{ }$ & $\sqrt{ }$ & $\sqrt{ }$ & $\sqrt{ }$ & $\sqrt{ }$ \\
\hline 7 & Analisis Standar Isi & $\sqrt{ }$ & $\sqrt{ }$ & $\sqrt{ }$ & $\sqrt{ }$ & $\sqrt{ }$ \\
\hline 8 & Analisis SKL Mata Pelajaran & $\sqrt{ }$ & $\sqrt{ }$ & $\sqrt{ }$ & $\sqrt{ }$ & $\sqrt{ }$ \\
\hline 9 & Standar Kompetensi & $\sqrt{ }$ & $\sqrt{ }$ & $\sqrt{ }$ & $\sqrt{ }$ & $\sqrt{ }$ \\
\hline 10 & Kompetensi Dasar & $\sqrt{ }$ & $\sqrt{ }$ & $\sqrt{ }$ & $\sqrt{ }$ & $\sqrt{ }$ \\
\hline 11 & Kriteria Ketuntasan Minimal & $\sqrt{ }$ & $\sqrt{ }$ & $\sqrt{ }$ & $\sqrt{ }$ & $\sqrt{ }$ \\
\hline 12 & Sistem Penilaian & $\sqrt{ }$ & $\sqrt{ }$ & $\sqrt{ }$ & $\sqrt{ }$ & $\sqrt{ }$ \\
\hline 13 & Agenda Kegiatan Harian & $\sqrt{ }$ & $\sqrt{ }$ & $\sqrt{ }$ & $\sqrt{ }$ & $\sqrt{ }$ \\
\hline 14 & Absensi Siswa & $\sqrt{ }$ & $\sqrt{ }$ & $\sqrt{ }$ & $\sqrt{ }$ & $\sqrt{ }$ \\
\hline 15 & Kisi-kisi dan Soal & $\sqrt{ }$ & $\sqrt{ }$ & $\sqrt{ }$ & $\sqrt{ }$ & $\sqrt{ }$ \\
\hline 16 & Kunci dan Pembahasan & $\sqrt{ }$ & $\sqrt{ }$ & $\sqrt{ }$ & $\sqrt{ }$ & $\sqrt{ }$ \\
\hline 17 & $\begin{array}{l}\text { Pelaksanaan Pembelajaran, Alokasi } \\
\text { Waktu } 45 \text { menit }\end{array}$ & $\sqrt{ }$ & $\sqrt{ }$ & $\sqrt{ }$ & $\sqrt{ }$ & $\sqrt{ }$ \\
\hline 18 & $\begin{array}{l}\text { Maksimal Jumlah Peserta Didika } 36 \\
\text { siswa }\end{array}$ & $\sqrt{ }$ & $\sqrt{ }$ & $\sqrt{ }$ & $\sqrt{ }$ & $\sqrt{ }$ \\
\hline 19 & Buku Teks Pelajaran & $\sqrt{ }$ & $\sqrt{ }$ & $\sqrt{ }$ & $\sqrt{ }$ & $\sqrt{ }$ \\
\hline 20 & $\begin{array}{l}\text { Pengelolaan } \\
\text { Laboratorium }\end{array}$ & $\sqrt{ }$ & $\sqrt{ }$ & $\sqrt{ }$ & $\sqrt{ }$ & $\sqrt{ }$ \\
\hline 21 & Kegiatan Pendahuluan & $\sqrt{ }$ & $\sqrt{ }$ & $\sqrt{ }$ & $\sqrt{ }$ & $\sqrt{ }$ \\
\hline 22 & Kegiatan Inti & $\sqrt{ }$ & $\sqrt{ }$ & $\sqrt{ }$ & $\sqrt{ }$ & $\sqrt{ }$ \\
\hline 23 & Kegiatan Penutup & $\sqrt{ }$ & $\sqrt{ }$ & $\sqrt{ }$ & $\sqrt{ }$ & $\sqrt{ }$ \\
\hline 24 & $\begin{array}{l}\text { Penilaian berupa Tugas, Proyek, } \\
\text { Portofolio, Penilain Diri }\end{array}$ & $\sqrt{ }$ & $\sqrt{ }$ & $\sqrt{ }$ & $\sqrt{ }$ & $\sqrt{ }$ \\
\hline
\end{tabular}




\begin{tabular}{|c|c|c|c|c|c|c|}
\hline 25 & Standar Penilaian Pendidikan & $\sqrt{ }$ & $\sqrt{ }$ & $\sqrt{ }$ & $\sqrt{ }$ & $\sqrt{ }$ \\
\hline 26 & $\begin{array}{l}\text { Panduan Penilaian Kelompok Mata } \\
\text { Pelajaran }\end{array}$ & $\sqrt{ }$ & $\sqrt{ }$ & $\sqrt{ }$ & $\sqrt{ }$ & $\sqrt{ }$ \\
\hline 27 & Program Perbaikan (Remedia) & $\sqrt{ }$ & $\sqrt{ }$ & $\sqrt{ }$ & - & $\sqrt{ }$ \\
\hline 28 & Pengayaan (enrichment) & $\sqrt{ }$ & $\sqrt{ }$ & $\sqrt{ }$ & $\sqrt{ }$ & $\sqrt{ }$ \\
\hline 29 & Pelayananan Konseling & $\sqrt{ }$ & $\sqrt{ }$ & $\sqrt{ }$ & $\sqrt{ }$ & $\sqrt{ }$ \\
\hline 30 & $\begin{array}{l}\text { Pemantauan Pada } \\
\text { Perencanaan }\end{array}$ & $\sqrt{ }$ & $\sqrt{ }$ & $\sqrt{ }$ & $\sqrt{ }$ & $\sqrt{ }$ \\
\hline 31 & $\begin{array}{l}\text { Pemantauan } \\
\text { Pelaksanaan }\end{array}$ & $\sqrt{ }$ & $\sqrt{ }$ & $\sqrt{ }$ & $\sqrt{ }$ & $\sqrt{ }$ \\
\hline 32 & $\begin{array}{l}\text { Pemantauan Pada Tahap Penilaian } \\
\text { Hasil Pembelajaran }\end{array}$ & $\sqrt{ }$ & $\sqrt{ }$ & $\sqrt{ }$ & $\sqrt{ }$ & $\sqrt{ }$ \\
\hline 33 & $\begin{array}{l}\text { Pemanatauan, } \\
\text { Pencatatan, } \\
\text { Dokumentasi }\end{array}$ & $\sqrt{ }$ & $\sqrt{ }$ & $\sqrt{ }$ & $\sqrt{ }$ & $\sqrt{ }$ \\
\hline 34 & $\begin{array}{l}\text { Pemantauan oleh Kepala dan } \\
\text { Pengawas Satuan Pendidikan }\end{array}$ & $\sqrt{ }$ & $\sqrt{ }$ & $\sqrt{ }$ & $\sqrt{ }$ & $\sqrt{ }$ \\
\hline 35 & $\begin{array}{l}\text { Supervisi Pada Tahap Perencanaan, } \\
\text { Pelaksanaan, Hasil Pembelajaran }\end{array}$ & $\sqrt{ }$ & $\sqrt{ }$ & $\sqrt{ }$ & $\sqrt{ }$ & $\sqrt{ }$ \\
\hline 36 & $\begin{array}{l}\text { Supervisi Dilakukan Diskusi, } \\
\text { Pelatiahan dan Konsultasi }\end{array}$ & $\sqrt{ }$ & $\sqrt{ }$ & $\sqrt{ }$ & $\sqrt{ }$ & $\sqrt{ }$ \\
\hline 37 & $\begin{array}{l}\text { Supervsisi Oleh Kepala dan } \\
\text { Pengawas satuan Pendidikan }\end{array}$ & $\sqrt{ }$ & $\sqrt{ }$ & $\sqrt{ }$ & $\sqrt{ }$ & $\sqrt{ }$ \\
\hline 38 & $\begin{array}{l}\text { Evaluasi Kualitas, Pelaksanaan, } \\
\text { Penilaian Pembelajaran }\end{array}$ & $\sqrt{ }$ & $\sqrt{ }$ & $\sqrt{ }$ & $\sqrt{ }$ & $\sqrt{ }$ \\
\hline 39 & Evaluasi Kinerja Guru & $\sqrt{ }$ & $\sqrt{ }$ & $\sqrt{ }$ & $\sqrt{ }$ & $\sqrt{ }$ \\
\hline 40 & $\begin{array}{l}\text { Evaluasi Standar Proses Kinerja } \\
\text { Guru }\end{array}$ & $\sqrt{ }$ & $\sqrt{ }$ & $\sqrt{ }$ & - & $\sqrt{ }$ \\
\hline 41 & $\begin{array}{l}\text { Evaluasi Kinerja Guru Sesuai } \\
\text { Dengan Kompetensi Guru }\end{array}$ & $\sqrt{ }$ & $\sqrt{ }$ & $\sqrt{ }$ & $\sqrt{ }$ & $\sqrt{ }$ \\
\hline 42 & $\begin{array}{l}\text { Penguatan dan Penghargaan } \\
\text { Kinerja Guru yang Memenuhi } \\
\text { Standar }\end{array}$ & $\sqrt{ }$ & $\sqrt{ }$ & $\sqrt{ }$ & $\sqrt{ }$ & $\sqrt{ }$ \\
\hline 43 & Pemberian Kesempatan PPG & $\sqrt{ }$ & $\sqrt{ }$ & $\sqrt{ }$ & - & $\sqrt{ }$ \\
\hline
\end{tabular}




\section{Pemahaman Pendidik terhadap standar proses}

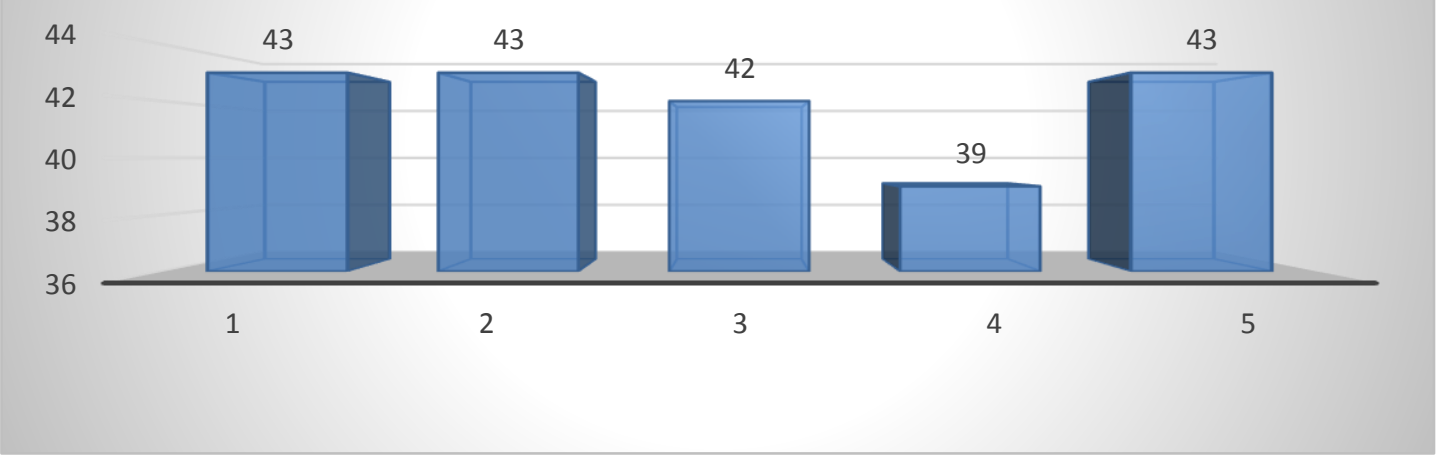

\section{Grafik 1. Profil Pemahaman Tenaga Pendidik terhadap Standar Proses}

Perbedaan pemahaman tenaga pendidik terhadap standar proses diduga ditentukan oleh jumlah pelatihan atau sosialisasi tentang standar nasional pendidikan. Demikian pula menyatakan bahwa kegiatan sosialisasi penting diberikan kepada tenaga pendidik termasuk guru.

Grafik 1 menunjukkan adanya perbedaan pemahaman guru-guru terhadap komponen standar proses pendidikan, namun sampel dari ke 5 (lima) guru tersebut sudah memenuhi ketercapainya stndar proses pendidikan, hanya grafik menunjukan dua orang guru yang sedikit lagi bisa memenuhi dari standar proses penddikan. Ketercapaian kualitas proses pembelajaran disekolah masih belum memenuhi pada standar kompetensi yang berlaku. Aspek yang belum maksimal dari standar proses pembelajaran meliputi: Rencana perangkat pembelajaran (RPP), namun pada RPP itu hanya sebagian yang belum tercapainya, bisa dikatakan sub-subnya dari isi RPP yang belum memenuhi pada standar proses. Evaluasi proses pembelajaran dan pemberian kesempatan PPG, pada pemberian kesempatan PPG hanya sebagian guru yang belum tetapi belum disini bisa dikatakan hanya menunggu antrian karena ada beberapa guru yang datanya masih valid untuk mengikuti PPG agar diperbaiki terlebih dahulu dan diajukan ulang. Standar profesioanal guru tercermin dari uji kompetensi. Uji kompetensi dilaksanakan dalam bentuk penilaian portofolio dan Pendidikan dan Pelatihan Profesi Guru. Pendidikan dan pelatihan profesi guru diakhiri dengan ujian yang mencakup empat kemampuan atau kompetensi yaitu kompetensi pedagogik, kompetensi kepribadian, kompetensi sosial, dan kompetensi profesional, dimana keempat kompetensi tersebut merupakan kompetensi utama yang harus dimiliki oleh guru. Dengan mengikuti diklat sertifikasi, maka guru bisa lebih banyak mendapatkan ilmu baru guna meningkatkan kemampuan atau kompetensinya tersebut. Dan pada gilirannya, ilmu yang mereka dapatkan di diklat sertifikasi diterapkan di sekolah atau di kelas. Dengan adanya sertifikasi, diharapkan kompetensi guru sebagai agen pembelajaran yang meningkat sesuai dengan standar yang telah ditetapkan. Dengan kompetensi guru yang memenuhi standar minimal, maka kinerja guru dalam mengelola proses pembelajaran dapat meningkat. Kualitas pembelajaran yang meningkat bermuara akhir pada terjadinya peningkatan prestasi hasil belajar siswa. (Murwati, 2013) 
2. Tabel distribusi hasil instrumen standar proses

Tabel 2. distribusi hasil instrument standar proses

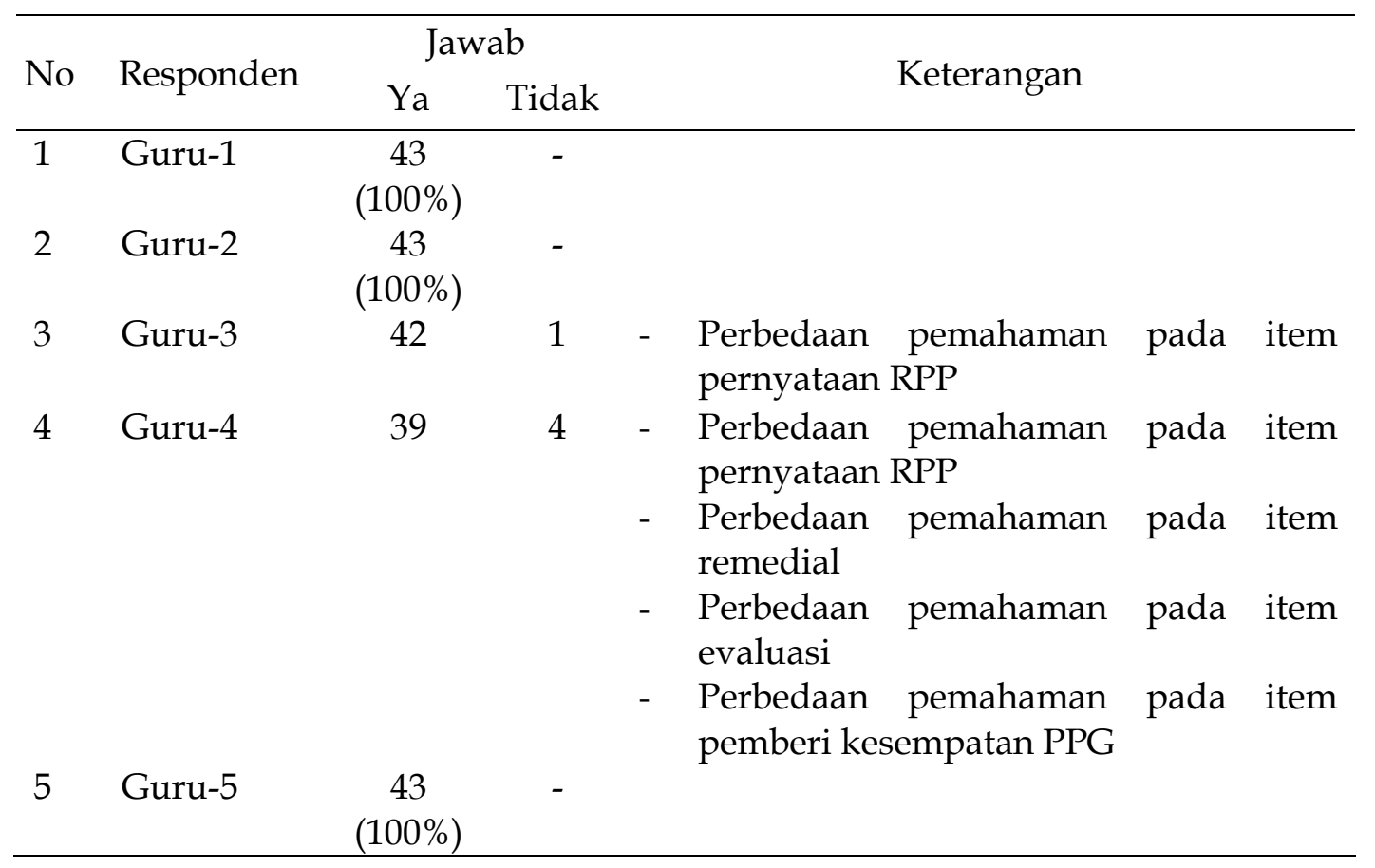

Table. 2 mengenai distribusi hasil instrument standar proses bahwa dari 5 guru yang memiliki pemahaman yang sama hanya 3 guru dengan prosentasi keseluruhan ialah $100 \%$. Artinya, antara 3 guru tidak terjadi perbedaan pemahaman mengenai standar proses tetapi, berbeda dengan pemahaman 2 guru, 2 guru ini kurang memenuhi dalam standar proses pendidikan.

Guru-3 dalam distribusi hasil instrumen standar proses perbedaan pada "RPP"menunjukkan adanya perbedaan antara pemahaman ke-2 guru terhadap komponen standar proses, pernyataan "RPP, media/alat/bahan dan sumber belajar", yang berkaitan dengan standar proses, pelaporan hasil standar proses, para guru-guru menjawab "TIDAK" sebanyak 2 guru. Perbedaan pemahaman antara guru-3 dengan guru-4, perbedaan terdapat pada guru-3 mengenai RPP item "media/alat/bahan, dan sumber belajar" dan 2 guru menjawab "TIDAK" dan 3 guru menjawab "YA". Hal yang demikian terjadi karena perbedaan pemahaman pendidik dengan 1 guru dan guru lainnya mengenai "media/alat/bahan dan sumber belajar, bahan yang dimaksud adalah segala sesuatu yang membawa pesan atau informasi untuk pembelajaran. Baik pesan itu dikemas dalam bentuk buku paket, video, film, bola dunia, grafik, CD interaktif dan sebagainya. Kelompok ini biasanya disebut dengan media pembelajaran. Demikian halnya dengan bahan ini, bahwa dalam penggunaannya untuk suatu proses pembelajaran dapat dibedakan menjadi dua kelompok yaitu bahan yang didesain khusus untuk pembelajaran, dan ada juga bahan atau media yang dimanfaatkan untuk memberikan penjelasan materi pembelajaran yang relevan.

Sumber belajar adalah merupakan informasi yang disampaikan dalam bentuk ide, makna, dan fakta, Manusia merupakan orang-orang yang bertindak sebagai penyimpan, pengolah dan penyalur pesan, bahan media software (materials) merupakan perangkat lunak yang biasanya berisi pesan, peralatan hardware (device) merupakan perangkat keras yang digunakan untuk menyampaikan pesan yang terdapat dalam bahan, teknik (technique) merupakan prosedur atau langkah-langkah tertentu dalam 
menggunakan bahan, peralatan, lingkungan, dan orang untuk menyampaikan pesan, latar (setting) merupakan lingkungan dimana pesan itu diterima oleh pembelajar. (Lilawati, 2017)

Guru-4 dalam distribusi hasil instrumen standar proses perbedaan pada "SILABUS" 'alokasi waktu sesuai dengan jumlah jam pelajaran dalam struktur kurikulum untuk satu semester atau satu tahun' "RPP" 'penilaian, pengayaan, dan remidial' "EVALUASI" 'membandingkan proses pembelajaran yang dilaksanakan guru dengan standar proses' "PENGAWASAN PROSES PEMBELAJARAN" 'pemberian kesempatan kepada guru untuk mengikuti program pengembangan keprofesionalan berkelanjutan'. Pada guru-4 menjawab keterangan tersebut dengan "TIDAK" sebanyak 1 guru dan 4 guru lainnya menjawab "YA"

Dalam program tahunan menjelaskan tentang rencana penetapan alokasi waktu satu tahun untuk mencapai tujuan (SK dan KD) yang telah ditetapkan. Penetapan alokasi waktu diperlukan agar seluruh kompetensi dasar yang ada dalam kurikulum seluruhnya dapat dicapai oleh sisiwa. penentuan alokasi waktu ditentukan pada jumlah jam pelajaran sesuai dengan struktur kurikulum yang berlaku serta keluasan materi yang harus dikuasai oleh siswa.

Program Tahunan merupakan program umum setiap mata pelajaran untuk setiap kelas yang dikembangkan oleh guru mata pelajaran yang bersangkutan program ini telah dipersiapkan dan dikembangkan oleh guru mata pelajaran sebelum tahun ajaran karena merupakan pedoman bagi pengembangan program-program berikutnya.

Remedial merupakan program pembelajaran yang diperuntukkan bagi peserta didik yang belum mencapai kriteria ketuntasan minimal dalam satu Kompetensi Dasar tertentu. Pembelajaran remedial diberikan segera setelah peserta didik diketahui belum mencapai kriteria ketuntasan minimal.Pembelajaran remedial dilakukan untuk memenuhi kebutuhan atau hak peserta didik. Dalam pembelajaran remedial, pendidik membantu peserta didik untuk memahami kesulitan belajar yang dihadapi secara mandiri, mengatasi kesulitan dengan memperbaiki sendiri cara belajar dan sikap belajarnya yang dapat mendorong tercapainya hasil belajar yang optimal. Dalam hal ini, penilaian merupakan assessment as learning. Pemberian nilai Kompetensi Dasar bagi peserta didik yang mengikuti pembelajaran remedial yang dimasukkan sebagai hasil penilaian harian.

Pengayaan merupakan program pembelajaran yang diberikan kepada peserta didik yang telah melampaui kriteria ketuntasan minimal. Fokus pengayaan adalah pendalaman dan perluasan dari kompetensi yang dipelajari. Pengayaan biasanya diberikan segera setelah peserta didik diketahui telah mencapai kriteria ketuntasan minimal berdasarkan hasil Penilaian Harian. Pembelajaran pengayaan biasanya hanya diberikan sekali, tidak berulang kali sebagaimana pembelajaran remedial. Pembelajaran pengayaan umumnya tidak diakhiri dengan penilaian. Namun pada guru-4 menjawab hal ini dengan "TIDAK" karena blm tercapai sesuai dengan standar nasional pendidikan akan tetapi pada 4 guru lainnya menjawab dengan "YA".

\section{SIMPULAN}

Berdasarkan analisis data dan pembahasan, maka diperoleh adanya variasi pemahaman tentang standar proses disekolah pada berbagai komponen pendidik dan tenaga kependidikan. Selain itu, ada pula variasi pemahaman guru-guru terhadap komponenkomponen dari standar proses yang dilaksanakan disekolah SMAN 1 Jatitujuh. Salah satu solusi untuk mengatasi variasi pemahaman tersebut ialah dengan meningkatkan kualitas dan menyesuaikan proses pembelajaran dengan karakteristik peserta didik 
maupun dengan tuntutan perkembangan zaman. Guru tidak menempatkan diri sebagai satu-satunya sumber ilmu bagi siswanya. Guru seharusnya lebih berperan sebagai fasilitator, motivator, dan konselor. Sebagai fasilitator, guru memberikan jalan pada kelancaran proses belajar secara mandiri siswanya.

\section{REFERENSI}

Anon., Februari 2012. Pengembangan Perangkat Pembelajaran Fisika. Jurnal Penelitian Pembelajaran Fisika, Issue ISSN: 2252-3014, pp. 1-19.

Moleong, L. J., 2013. Metodologi Penelitian Kualitatif. Edisi Revisi ed. Bandung: Rosda Karya.

U.S., S., n.d. Arah Pendidikan Di Indonesia. Jurnal Formatif, Issue ISSN: 2088-351X, pp. 111-121.

Chodijah, S., \& Ahmad Fauzi, dan R. W. (2012). Pengembangan Perangkat Pembelajaran Fisika Menggunakan Model Guided Inquiryyang Dilengkapi Penilaian Portofolio Pada Materi Gerak Melingkar. Jurnal Penelitian Pembelajaran Fisika 1, (ISSN: 22523014). Retrieved from http://ejournal.unp.ac.id

Manoppo, Y. K. (2014). Analisis penerapan standar proses pembelajaran pendidikan agama islam di smp negeri 2 kota gorontalo. Tadbir: Jurnal Manajemen Pendidikan Islam, Vol 2, No. Retrieved from

http://www.journal.iaingorontalo.ac.id/index.php/tjmpi\%0Aanalisis penerapan

Murwati, H. (2013). Pengaruh Sertifikasi Profesi Guru Terhadap Motivasi Kerja Dan Kinerja Guru Di Smk Negeri Se-Surakarta. Jurnal Pendidikan Bisnis Dan Ekonomi (BISE), Vol.1, 12. Retrieved from https://eprints.uns.ac.id/1083/1/1896-4270-1SM.pdf

Rahmawati, Desi Anggraini, A. D. (2017). Evaluasi Program Kurikulum Berdasarkan Standar Isi, Standar Proses, Dan Standar Kompetensi Lulusan Di Sdn Pisangan Timur 10 Pagi. Jurnal Pendidikan Ekonomi Dan Bisnis (JPEB), Vol 5 No 1(2302-2663, 10.21009/JPEB,). Retrieved from http://journal.unj.ac.id/unj/index.php/jpeb 